Alev Müezzinoğlu, Başak Gorgoretti

Doğu Akdeniz University, Gazimağusa-Turkish Republic of Northern Cyprus

alev.muezzinoglu@emu.edu.tr; basak.guler@emu.edu.tr

\begin{tabular}{l|l|l|l}
\hline \hline DOI & \multicolumn{3}{|l}{$\mathrm{http}: / / \mathrm{dx} . \mathrm{doi}$. org/10.12739/NWSA.2019.14.3.D0242 } \\
\hline ORCID ID & $0000-0003-1866-7623$ & $0000-0002-0656-0688$ \\
\hline \multicolumn{2}{l|}{ CORRESPONDING AUTHOR } & Başak Gorgoretti \\
\hline \hline
\end{tabular}

\title{
The New Music Curriculum With A New Music Education Concept
} ABSTRACT

The change and developments in the world have led to discussions on the concept of contemporary music education. Changing learner profiles, music teaching approaches adapted to present, and the changes in the way people perceive music, there is now a need for revision in music curriculums. Globalization and the rapid advances in technology at present point towards a need to revise and change the contents of the curricula. The Turkish Republic of Northern Cyprus Basic Education program development project was initiated in 2013, and the curricula for all courses came into force in 2016. In the first part of the study, the structure of the TRNC new music curriculum, the learning areas, and the relation between the curriculum and the learning outcomes are discussed. Next, the characteristics of the intended student profile together with the curriculum are explained, and the local and universal elements dealt within the curriculum are exhibited. Finally, ideas and suggestions are proposed.

Keywords: Curriculum, Listening, Performing, Creating, Competence

\section{INTRODUCTION}

The change and developments in the world have led to discussions on the concept of contemporary music education. Due to the improvements in the practices of music education, changing learner profiles, the importance of music education approaches, such as Kodaly, Orff and Dalcroze on music applications, and the changes in the way people perceive and experience music, there is now a need for revision in music curriculums. Globalization and the rapid advances in technology at present point towards a need to revise and change the contents of the education curricula (Christophersen, 2014). After 1974, Cyprus turned into a bi-communal island, and since then, just like in many other fields, the Turkish Cypriot society has shown improvements in parallel with Turkey. In this light, without considering the needs of the Turkish Cypriot society in Cyprus and regardless of the historic, cultural and social differences between the Turkish Cypriot and Turkish (from Turkey) societies, curricula were brought from Turkey and applied in Cyprus as they were. However, after a while, problems that occurred during the application of these programs caused teachers to follow a book based, program-free education concept' (Ministry of Education, 2017) and this continued for some time. The first music curriculum designed to meet the needs of the Turkish Cypriot society was prepared by the Ministry of Education, and it was put into practice in 2007 for the first time. This program is designed for music classes that last 8 years during primary and secondary school education. The program is based on national culture, and at the same time, it has a quality that aims to

How to Cite:

Müezzinoğlu, A. and Gorgoretti, B., (2019). The New Music Curriculum with A New Music Education Concept, Fine Arts (NWSAFA), 14(3):247-253, DOI: 10.12739/NWSA.2019.14.3.D0242. 
unify local culture with universal culture. In the curriculum, the units are not only built upon and progressive from $1^{\text {st }}$ to $8^{\text {th }}$ year, but they are also based on listening, performing, creating, transforming and interpreting (KKTC Milli Eğitim ve Kültür Bakanlığı,2014). Along with the ongoing changes and developments in the world, it was later agreed to plan and prepare a new curriculum for music education in TRNC, which was also in accordance with the new perception of music education in the world. In line with this decision, the TRNC Basic Education program development project was initiated with the cooperation of the Ministry of National Education and the Eastern Mediterranean University in TRNC in 2013, and the curricula for all courses came into force in 2016. The new curriculum is the product of a collaborative work by academicians in the field of music, and music teachers in primary and secondary schools. In addition, teacher and student books are written for each class to be used in music lessons. During the design of this new music program, many cultural, historical, political, economic, social and national key aspects are considered. Furthermore, during the preparation of the program, the two most discussed subjects on the agenda are how the change in our perception of teaching and learning will be dealt with in programs, and which values will be incorporated into these. As for technology, creativity and innovation, they are the important dynamics that affect change. The individual may change and adapt according to the needs of the community and subject area; he or she can maintain the dynamic structure of the program towards development and interaction in terms of its factors regarding its aims, education circumstances, teaching/learning processes, and its assessment and evaluation (Coşkun, 2017).

\section{RESEARCH SIGNIFICANCE}

In this study, the primarily discussed aspects are the structure of the new music curriculum, the learning areas it contains, and the relation between the curriculum and the learning outcomes. Next, the characteristics of the intended student profile together with the curriculum are explained, and the local and universal elements dealt within curriculum are exhibited. Finally, ideas and suggestions about the kind of approach to be adopted while writing the new music curricula in the frame of global music education are proposed. The following questions are discussed on which bases should the new music curriculum be structured? Is it possible to create a curriculum that is designed with an understanding of global music education? Answers to questions were sought in order to discuss what new understanding of writing music teaching program might be.

\section{METHOD}

A descriptive approach was used in the study. Descriptive approaches aim to describe the state of a current situation or as it existed in the past (Karasar, 2003). Data were collected through document analysis. Data were analyzed using content analysis. In this research, music curricula for the $1^{\text {st }}$ to the $8^{\text {th }}$ grades were examined in terms of structure, learning areas and the relation between the curriculum and the learning outcomes. The data related to the characteristics of the intended student profile together with the curriculum and the local and universal elements dealt within the curriculum are analyzed.

\section{FINDINGS AND DISCUSSIONS}




\subsection{Structure and Content Strands of the New Music Curriculum}

Although music curriculum appears as the predesigned plan of the music education process and the way it manifests itself in practice, it is in fact also defined as the group of qualities which bring learners, content (subject matter), the instructor, and the environment together, combine, integrate and turn them into an educational system' (Uçan, 2005). TRNC new music curriculum has been designed in order to be applied in music education through primary and secondary education. The qualities which are to be found in the $21^{\text {st }}$ century learner profiles, instructor needs, country realities and the developments in the world have all been taken into consideration during the design of the new music curriculum. As a common feature with curricula of other courses, this new curriculum has been developed in a student-centered way, taking into account the principles of progressivism and restructuring philosophies. In addition, the whole curriculum has been prepared with an eclectic approach.

The aim of the new music curriculum in TRNC is specified as raising learners who are interested in music, are able to use basic music knowledge, are musically developed, are aware of the local and universal music culture as well as those who enjoy music events, who can benefit from technology in different areas of music, who can express themselves by using musical creativity, and those who have a sense of aesthetics (KKTC Milli Eğitim ve Kültür Bakanlığı,2017). Music classes in TRNC begin at the age of 6 and last 8 years through the duration of compulsory education. Contact hours allocated to music classes per week are 2 in the primary, 1 in the secondary and 2 hours in the form of elective lessons in high school. Changing learner profiles cause alterations in the way music lessons are carried out and listening, performing and creating strands are considered complementary to one another in these lessons, which are handled according to a holistic approach. Orff, Dalcroze and Kodaly introduced new methods that constituted the foundations of modern music education in the late 19th and early 20th centuries (Bravo, Molto and Bravo, 2015). While structuring the new curriculum, Orff and Kodaly-based and supported approaches, which are widely used in teaching methods today, were frequently observed. In this light, these approaches were applied in the new curriculum in order to enable interaction and connection between the learning strands. In addition, these approaches also brought light while structuring various music strands. That is, the curriculum was structured in a way that students could develop their skills in exploring sounds and responding to them in the listening strand, expanding their skills in singing, playing instruments and improving their theory of music in the performing strand, and better their capabilities in responding through notation, movement, dance and sound, as well as improvising and composing in the creating strand. Music lessons should be carried out in a way that the theoretical subjects are applied in practice, active learner participation is ensured and different qualities of the learners are taken into consideration. Thus, it is specifically pointed out that the theoretical knowledge presented during music lessons in primary education institutes is not supported by practice and therefore education does not reach its aim (Sevgi, 2003). In the new curriculum, the importance of transferring and assimilating the knowledge learned are greatly emphasized. Furthermore, due to the fact that there is not just one correct way of improvisation and interpretation in creating strands, issues like executing music lessons with a sense of freedom and not having set boundaries are highlighted in the new curriculum. 
For these reasons, the new music curriculum has been designed to suit today's conditions and it is realistic. With this curriculum, it is also aimed to help learners gain primary dimensions of music education, such as music culture, music theory, singing, listening, music appreciation, and musical creativity. The new music curriculum has been developed in three content strands in order to provide students with versatile musical skills. These strands are listening, performing and creating. The new curriculum has been designed in a spiral way so that the subject matter is organized from simple to complex, concrete to abstract and close to far, and it is extended and deepened progressively starting from the $1^{\text {st }}$ grade up. Examples of activities that can be done in order to reach the learning outcomes and tips on how far the content can be expanded are included in the instructions. The new curriculum also includes musical concepts which are related to learning outcomes, skills to be gained, and common disciplines.

Table 1. The strands and strand units of the new music curriculum

\begin{tabular}{|c|c|c|c|}
\hline Strands & Strand Units & & \\
\hline Listening & Exploring Sounds & $\begin{array}{l}\text { Responding } \\
\text { to Sounds }\end{array}$ & \\
\hline Performing & Singing & $\begin{array}{l}\text { Playing } \\
\text { Instruments }\end{array}$ & Theory of Music \\
\hline Creating & $\begin{array}{l}\text { Responding through Notation, } \\
\text { Movement, Dance and Sound }\end{array}$ & Improvising & Composing \\
\hline
\end{tabular}

Learning outcomes specified in the listening strand are structured in order to enable learners to get to know the qualities of sound, to get in the habit of listening to music regularly, to acquire a good taste in music, and to recognize the qualities that music comprises. The Performing strand is primarily composed of learning outcomes which include singing, introducing standard notation, instrument education, music culture, rhythm education, body percussion and national day celebration and commemoration events. Creating strand includes learning outcomes which facilitate creativity like composing, instrument designing, improvisation, using technology, drama, dance, and visual-audio structuring (KKTC Milli Eğitim ve Kültür Bakanlığı, 2017). When we look at the relationship among the learning strands of the new curriculum, we can see that the strand with the highest number of outcomes which include both theory and practice is the performing strand. In the new curriculum, where all the strands are interrelated and integrated, the outcomes in the listening strand are achieved by evoking senses through listening activities. Secondly, the outcomes of performing strand are reached by grasping, perceiving, and performing. Finally, the outcomes of the creating strand are gained through designing and producing. The Listening strand is an important innovation which stands out in the new curriculum. This strand, which was not found in previous curricula, aims to help learners acquire effective listening skills and be able to transfer these skills to other strands of music.

\subsection{Intended Learner Profile in the New Curriculum}

With the new curriculum, it is aimed to transform learners into self-confident, social, tolerant, cooperative, creative individuals who are willing to share, have effective communication skills, good psychomotor skills, aesthetic appreciation, and a critical view towards arts and can use technology in music studies (KKTC Milli Eğitim ve Kültür Bakanlığı, 2017)). Music education enables individuals to utilize music to socialize and establish a relationship 
with their immediate circle, as well as become individuals who produce and consume music consciously (Özen, 2004). Research in the cognitive field has revealed that active involvement in music brings about the development of perceptual skills, which facilitate language learning in childhood, and literacy later on, as well as developing motor skills, coordination and spatial reasoning. It is also believed that producing music actively has a positive effect on the intellectual development of the individual (Hallam, 2010). Instrument education provided in schools improves verbal memory and the abilities to transfer cognitive skills acquired during music playing into language learning (Roden, Kreutz, Bongard, 2012). With the new curriculum, it is aimed to create a versatile learner profile in the music study. Even though the performing strand seems like a theoretical strand, it is in fact one, where the expectations for experiencing music are high. The significance of experiencing music is also pointed out and achieving the aims of experiencing music is targeted in the national music curricula of England and Austria (Özmenteş, 2007). To illustrate, in the new TRNC music curriculum, the outcomes of 'participates in music activities willingly', 'sings', 'enjoys doing research on music', and 'creates by composing and improvisation' are the learning outcomes which are aimed to be acquired by the end of the work done in the performing strand. In order to reach such an outcome of the curriculum, it is essential that all the learning strands work in relation with one another.

\subsection{Universal and Local Elements Present in the New Music Education Curriculum}

In the New Music education curriculum, local and universal elements are used together. Owing to the new curriculum, nursery rhymes and counting out rhymes known and told in TRNC, as well as folk songs and children's songs are now included in course books. In addition to what is listed above, Turkish classical music Maqams, Turkish rhythms, such as 5/8, 7/8, 9/8 meters, and instruments and performances are also included in the new curriculum. Furthermore, learning outcomes of the new curriculum also encompass both the Turkish music revolution, and celebrations and commemorations regarding the national days. The new music curriculum also proposes that teachers include folk songs and anthems in their lessons so that with the folk songs they can keep samples of local music culture alive, and with the anthems, they can emphasize the importance of national unity and solidarity. Local music practices are highlighted especially in the creating strand not only through local folk songs, but also in rhythm and body percussion practices in which Turkish rhythm is used. The parts which are addressed by using Western methods and approaches in the new curriculum are note and rhythm teaching, practical activities which facilitate the development of creativity supported by Orff-Schulwerk, Kodaly and Dalcroze methods, sample sounds in the listening strand, which are recommended during the instruction of music concepts, and body percussion. On the other hand, when we analyze the new curriculum in terms of universality, we can see similarities with the aims of the arts and culture education in Europe, which are in the categories of " knowledge and appreciation of artistic ability; ability to question aesthetically; diversity of cultural heritage and cultural diversity; development of individual expression; and creativity " (Chen, 2016).

\section{CONCLUSION AND RECOMMENDATIONS}

Music education, which constantly shapes with the changes and developments in the world, leads to reconsideration of present music 
curricula and discussions on what a curriculum with a new music education concept should be like. In his research comparing the similarities of music curricula of several countries, chen (2016) lists the similarities as appreciating the value of art, developing the artistic competencies all through life, the importance of arts in our lives, and awareness and understanding of the interconnection between art education and interdisciplinary relationships. One of the ideas put forward with this article is that other competencies related to the new music education concept should be added to musical competencies which are already primarily present in the new TRNC music curriculum when future music curricula are designed. When we consider the innovations that can be done in the curriculum with the emphasis on students, the following competencies can be listed among the ones that the students need to acquire. It is envisaged that individuals, who encounter new music genres regularly in today's rapid globalizing world, should gain awareness of local and universal cultures, 'principles of authenticity and social justice should be promoted through a multicultural music education model' (Baxter, 2007), and global competencies like democracy, equality and diversity should be acquired through curricula. At the same time, new curricula aim to help learners develop new ideas and perspectives, use technology and multimedia to improve their creativity, and adapt to current conditions in the world.

The way teachers perceive and apply the new curricula has great importance. In other words, the primary responsibilities of understanding the learning styles of today's youth, questioning the way they perceive music, and finding ways to help them acquire an international and multicultural perspective in music all belong to teachers. For this reason, when teachers are executing the new curriculum, they should consider factors, such as values, novelties and needs and scrutinize ways of transferring these to the learners while trying to reach the learning objectives.

When we view the contents of the new curriculum, we can see that besides the traditional subjects taught throughout the years, it also comprises new and up-to-date subjects. To illustrate, we can show the examining of the social lives of dead composers by looking at their biographies as one of the subjects which lost their popularity in time (Skelton, 2004). In this respect, we should point out the importance of subjects which have great historical value, developments in technology, however, guide teachers in finding out new and different ways of exploiting these subjects (Bravo, Molto and Bravo, 2015). On the other hand, the ways in which the subjects of musical culture are dealt with, and the learning competencies which are aimed to be obtained through them are also important aspects that are drawn attention to. For instance, the subject of cultural awareness can be taught through a short folk song. Barbara Lundguist and Szego (1998) stated that it would take a long time to get accustomed to a music tradition; however, it is more likely that people will get to know and understand a short music piece and gain insights into the place that piece has in people's lives. Furthermore, such a piece would also help a student with the awareness of world music culture to gain a multicultural perspective.

As a result, with the changing world, the fact that competencies, which are aimed to be acquired through revised curricula, should include the development of social competencies, as well as musical ones will continue to be discussed. It is suggested that there should be a balanced distribution of locality and universal elements in curricula in order to raise individuals who are equally aware of their own culture and diverse cultures in the world. 
Consequently, it can be foreseen that the intended learner profiles can be achieved by employing universal techniques and methods in teaching local musical elements, and taking advantage of technology, which will eventually take us one step forward towards the type of individuals that are targeted by global music education.

\section{REFERENCES}

- Baxter, M., (2007). Global Music Making a Difference: Themes of Exploration, Action and Justice. Music Education Research, 9(2):267-279.

- Hernández-Bravo, J.R., Cardona-Moltó, M.C., and Hernández-Bravo, J.A., (2016). The Effects of an Individualized ICT-based Music Education Programmed on Primary School Students' Musical Competence and Grades. Music Education Research, $18(2)$ :176-194.

- Chen, H.F., (2016). New directions for Music Curriculum: An Examination of the Foundation and Goals of Art Programs in Selected Countries. International Society for Music Education 32nd World Conference on Music Education Glasgow, Scotland. Glasgow, Proceedings Book from ISME 2016.

- Christophersen, C., (2015). Changes and Challenges in Music Education: Reflections on a Norwegian Arts-in-education Programmer. Music Education Research, $17(4)$ :365-380.

- Coşkun, Y.D., (2017). Öğretim Programları Arka Plan Raporu. Retrieved from egitimreformugirisimi.org.

- Hallam, S., (2010). The Power of Music: Its Impact on the Intellectual, Social and Personal Development of Children and Young People. International Journal and Music Education, $28(3): 269-289$.

- Karasar, N., (2003). Bilimsel Araştırma Yöntemi. (sekizinci basım). Ankara: Nobel Publishing.

- KKTC Milli Eğitim ve Kültür Bakanlığı, (2014). Müzik Eğitimi Öğretmen El Kitabı "İlköğretim İkinci Kademe 4. ve 5. Sınıflar. Lefkoşa: Okman Printing.

- KKTC Milli Eğitim ve Kültür Bakanlığı, (2017). Müzik Dersi Öğretim Programı 1-8. Sınıflar. Lefkoşa: Okman Printing.

- Lundquist, B.R. and Szego, C.K., (1998). In: B. Nettl, R. Santos \& E. Solbu (Eds) Musics of the World's Cultures: A Source Book for Music Educators (Nedlands, Western Australia, Callaway International Resource Centre for Music Education).

- Özen, N., (2004). Çalgı Eğitiminde Yararlanılan Müzik Eğitimi Yöntemleri. Gazi Eğitim Fakültesi Dergisi, 24(2):57-63.

- Özmenteş, G., (2007). 38 th Icanas International Congress of Asian and North African Studies Music Culture and Music Education, Papers Volume I, Ankara, Turkey.

- Roden, I., Kreutz, G., and Bongard, S., (2012). Effects of a School-Based Instrumental Music Program on Verbal and Visual Memory in Primary School Children: A Longitudinal Study. Frontiers in Neuroscience, 6, 572.

- Sevgi, A., (2003). Nasıl Bir Müzik Öğretmeni?. Cumhuriyetimizin 80. Yılında Müzik Sempozyumu Bildiri Kitabı, Inönü Üniversitesi, Pegem A Yayıncılık.

- Skelton, K.D., (2004). Should we study music and/or as culture? Music Education Research, 6(2):169-177.

- Uçan, A., (2005). Müzik Eğitimi Temel Kavramlar-IlkelerYaklaşımlar Ve Türkiye'deki Durum. (Genişletilmiş 3. Basım). Ankara, Turkey, Evrensel Müzikevi. 